\title{
HONEY BEE ATTRACTANTS AND POLLINATION IN SWEET ORANGE, Citrus sinensis (L.) OSBECK, VAR. PERA-RIO
}

\section{MALERBO-SOUZA D. T. ${ }^{1}$, NOGUEIRA-COUTO R. H. ${ }^{2}$, COUTO L. A. ${ }^{3}$}

\author{
${ }^{1}$ Departamento de Ciências Agrárias, Centro Universitário Moura Lacerda, Ribeirão Preto, São Paulo, \\ Brasil, Departamento de Zootecnia, Faculdade de Ciências Agrárias e Veterinárias, Universidade \\ Estadual Paulista (UNESP), Jaboticabal, São Paulo, Brasil; ${ }^{3}$ Faculdade de Agronomia de Ituverava, São \\ Paulo, Brasil.
}

ABSTRACT. This experiment studied the frequency and behavior of insects on sweet orange flowers, Citrus sinensis (L.) Osbeck, their effect on fruit production (quantity and quality), nectar and pollen collection, and the effectiveness of different attractants. Over three consecutive years, the most frequent visitor to the flowers was Apis mellifera (Africanized). Flowers visited less than ten times showed low fructification. Fruit production was $35.30 \%$ greater in uncovered flowers. Fruit mean weight was much greater in uncovered (180.2g) than in covered flowers (168.5g). Fruits from the covered were more acid (1.411g of citric acid/100ml of juice) than the uncovered flowers (1.164g of citric acid/100ml of juice). The number of seeds per bud was higher in the uncovered ( 1 seed/bud) than in the covered treatment $\left(0.8\right.$ seed/bud). Bee-Here ${ }^{\mathrm{R}}$, eugenol, geraniol, citral, and lemon grass extract, mainly diluted in water, were effective in attracting honeybees to orchards. However, these compounds were less effective when diluted in sugar syrup. The same products had variable attractiveness to honeybees in different years.

KEY WORDS: attractants, Citrus sinensis var. Pera-Rio, pollination, Apis mellifera.

\section{CORRESPONDENCE TO:}

D. T. MALERBO-SOUZA, Departamento de Ciências Agrárias do Centro Universitário Moura Lacerda, Av. Dr. Oscar de Moura Lacerda, 1520, Jd Independência, 14.076-510, Ribeirão Preto, São Paulo, Brasil. E-mail: darclet@ig.com.br 


\section{INTRODUCTION}

Pollination by honeybees, Apis mellifera (L.), is essential for the production of many fruits and vegetables, not only in terms of individual crop production but also because proper pollination is often closely associated with fruit, vegetable, and seed quality. However, many crops still experience inadequate pollination, resulting in reduced yields, occasional crop failures, and lowered crop quality $(7,9,15,22)$.

The problem in pollination management is to attract bees to target crops and away from more attractive competing blooms (6). Also, the ability to attract bees from a compatible pollen source to the target crop would be desirable to ensure cross-pollination.

Many substances have been tested as honeybee attractants, some promising $(1,9,14,24,26,27)$. Some researchers have studied the attractiveness of honeybee pheromones, including the worker Nasanov pheromone $(9,13,14,16,26)$ and queen mandibular gland pheromone $(3,17)$.

Some authors have observed increased numbers of honeybees in onion and in apple crops when citral and geraniol were used, respectively $(18,28)$.

Others have reported significant increases in yield following applications of an attractant; increased forager activity was also reported at pheromone-sprayed plots, but the effect lasted only 1-2 days after applications (3).

Many experiments on pollination in Citrus sp have confirmed higher fruit production when bees are present $(2,8,10-12,19,21,23,25,29)$.

The aim of this work was to study the frequency and behavior of honeybees on sweet orange flowers, their effect on fruit production (quantity and quality), nectar and pollen collection, and the effectiveness of different attractants.

\section{MATERIALS AND METHODS}

This study was performed at the Faculdade de Ciências Agrárias e Veterinárias de Jaboticabal, UNESP (Brazil), located at an altitude of $595 \mathrm{~m}, 2^{\circ} 15^{\prime} 22^{\prime \prime S}$ and $48^{\circ} 18^{\prime} 68^{\prime \prime} \mathrm{W}$; the mean regional temperature is $21^{\circ} \mathrm{C}$; the climate is subtropical with an average annual precipitation of $1431 \mathrm{~mm}$. 
D. T. Malerbo-Souza et al. HONEY BEE ATTRACTANTS AND POLLINATION IN SWEET ORANGE, Citrus sinensis (L.) OSBECK, VAR. PERA-RIO. J. Venom. Anim. Toxins incl. Trop. Dis., 2004, 10, 2, p.146.

Observations on flowering and fructification were made in a sweet orange, Citrus sinensis (L.) Osbeck, var. Pera-Rio orchard from August to October 1993, September to October 1994, and December 1995.

The crop was under observation throughout the whole flowering period, and the following aspects were studied:

- development period: 100 flowers during bud phase until the flower withered (four replications);

- concentration of sugars: in collected nectar from A. mellifera worker honey-stomachs were dissected out 0800, 1000, 1200, 1400, and 1600 hours (four replications);

- estimate quantity of total dissolvable carbohydrates in flower nectar collected at 0800, 1000, 1200, 1400, and 1600 (four replications) in flowers of the same age (20);

- effective pollination period: 120 flower buds were marked and covered at sunset, 30 were uncovered at 0800, 30 at 1000, 30 at 1200, and 30 as controls (uncovered);

- number of visits for efficient pollination: 20 flowers were covered after 1, 3, 5, 7, 9, 10, and 15 honeybee visits with nylon netting lined wired cages (two replications);

- percentage of flower buds transformed in fruits: 100 flower buds were marked (three replications);

- fructification percentage: 200 flower buds were marked, 100 covered with nylon netting lined wired cages to impede cross pollination, and 100 flower buds uncovered marked with colored thread (four replications);

- collection and identification of the most frequent insects;

- frequency of visits during the day by counting the number of insects that visited flowers in the first 10 minutes of each hour from 0800 to 1700 hours (four replications);

- pollen and/or nectar collection of the most frequent insects (thirty replications);

- observation of damage caused by Trigona spinipes stingless bee in fructification; were marked 150 flower buds perforated and 150 not perforated;

- number, weight (g), size (cm), and pulp thickness (mm) of fruits after uncovered and covered treatments measured by SOMET-INOX paquimeter (ten replications); 
- juice percentage, acidity (g of citric acid/100g of juice), total soluble solids ( ${ }^{\circ}$ Brix), and quantity of seeds per fruit and per bud in 20 fruits after uncovered and covered treatments.

In September 1993 Bee-Here ${ }^{\mathrm{R}}$ (Hoescht Shering Agrevo do Brasil Ltda) was evaluated as a honeybee attractant applied to sweet orange by a manual sprayer and diluted in sugar syrup and water. They were applied at 0800, 1000, 1200, and 1400 hours, with three replications. In 1994, lemon grass, Cymbopogon citratus, extract and Bee-Here ${ }^{\mathrm{R}}$ were evaluated diluted only in water. They were applied at 0800, 1000, and 1200 hours, with three replications. In December 1995, eugenol, citral, and geraniol (SIGMA), Bee-Here ${ }^{\mathrm{R}}$, and lemon grass extract were evaluated diluted in water. They were applied only at 0800 hrs, with three replications. All dilutions were $0.2 \%$ ( $2 \mathrm{ml}$ of attractant for $1,000 \mathrm{ml}$ of sugar syrup or water); sugar syrup consisted of water (50\%) and sugar (50\%).

Visit frequency was determined by counting the number of honeybees visiting flowers in the trees over a five-minute period in each hour from 0800 to 1700 hrs after attractant applications.

Data were analyzed by analysis of variance using AVCTT that includes Tukey Test for comparison of averages of all variables and analysis of regression to test each variable in the time (from 0800 to 1700 hrs). Data at 5\% were considered significant.

\section{RESULTS AND DISCUSSION}

The average duration of sweet orange flowers, Citrus sinensis (L.) Osbeck, var. Pera-Rio, during bud phase until withering was 25 hours.

Concentration of sugars in the nectar collected from A. mellifera workers foraging on orange flowers was $29.5 \pm 1.3 \%$ on average, and the mean quantity of total dissolvable carbohydrates was $218.86 \pm 97.39 \mu \mathrm{g}$ of glucose/flower on average. These values were not different when considering the different time (0800, 1000, 1200, 1400, and 1600 hrs). A Brazilian study has shown an average of $28.2 \pm 1.9 \%$ and $186.92 \mu$ g of glucose/flower, respectively, in the same variety (11).

When comparing flowers open to bee visitation after 0800 hrs to those covered until 1200 hrs, the first showed less fructification (66.3\%) than the second (57.5\%), although the values were not statistically different. Comparing these data with frequency and nectar/pollen collection, it 
D. T. Malerbo-Souza et al. HONEY BEE ATTRACTANTS AND POLLINATION IN SWEET ORANGE, Citrus sinensis (L.) OSBECK, VAR. PERA-RIO. J. Venom. Anim. Toxins incl. Trop. Dis., 2004, 10, 2, p.148.

was observed that bees preferred to collect pollen until $1000 \mathrm{hrs}$ in these flowers. This can be explained because this period is very important for pollination in this crop, and pollen gatherers are the most effective pollinators (4).

The flowers that received up to 9 honeybee visits showed lower fructification $(56.5 \%$ on average) than those receiving 10 to 15 visits (83.7\% on average). This demonstrated the importance of good pollination and reinforced the need for a high density of honeybees in this crop. It was also observed that a greater number of honeybee visits on the flowers increased fructification.

It was observed that $88.1 \pm 3.14 \%$ of 300 uncovered flower buds marked in crop began fructification in 1993, without effectively developing into fruit. This may have occurred due to climate factors like the wind that blows fruit off or by natural abortion due to excessive fruit load in the tree. In 1994, 40.6\% began fructification but only 6.33\% completed fruit development.

Apis mellifera (66.0\%) and Trigona spinipes (34.0\%) bees were the only visitors to these flowers in 1993. In 1994, A. mellifera bees were almost exclusively responsible for the visits to sweet orange flowers, with sporadic visits by Xylocopa bees. $T$. spinipes stingless bees were not seen.

Honeybees preferred to collect nectar (94.4\% on average) than pollen (5.6\%) in sweet orange flowers during the three-year-observation period.

T. spinipes stingless bees presented a peculiar behavior of perforating flower buds to collect nectar; however, even so flowers opened and fertilized normally. From the 150 perforated flower buds, 131 were fertilized (87.3\%); this number was not significantly different in relation to the control treatment (88.1\%). T. spinipes frequent presence and the great number of perforated flowers did not reduce fructification in 1993.

In 1995, the fruit was analyzed for weight, size, pulp thickness, juice percentage, acidity, total soluble solids, and number of seeds per fruit and bud (Table 1).

Fruit production was $35.30 \%$ higher in uncovered flowers, and the mean fruit weight was also higher in uncovered flowers $(6.9 \%)$. Mean fruit size $(7.1 \times 6.8 \mathrm{~cm})$, pulp thickness value $(4.78$ $\mathrm{mm}$ ), juice percentage (45.30\%), total soluble solids (11.31 ${ }^{\circ}$ Brix), and number of seeds per fruit (8.15) were not significantly different for the uncovered and covered treatments. Fruits from the covered treatment were more acid (21.2\%) and yielded fewer seeds per bud (20.0\%). In Brazil, 
fruit from the covered treatment were smaller (13.3\%), more acid (5.7\%), had fewer seeds per fruit (50.5\%), and a lower vitamin C level in Pera-Rio and Valencia orange varieties (11).

Data prove honeybee visitation benefit in sweet orange orchards for both orange growers and beekeepers.

Table 1. Average characteristics observed in sweet orange (Citrus sinensis L. Osbeck, var. PeraRio) in fruits from uncovered and covered flowers in 1996.

\begin{tabular}{lccc}
\hline & & Treatments & \\
\cline { 2 - 4 } Fruit Characteristics & Uncovered & Covered & Mean \\
\hline Number & $23.0^{\mathrm{a}}$ & $17.0^{\mathrm{b}}$ & 20.0 \\
Weight (g) & $180.21^{\mathrm{a}}$ & $168.50^{\mathrm{b}}$ & 174.35 \\
Height(cm) & $7.20^{\mathrm{a}}$ & $7.00^{\mathrm{a}}$ & 7.10 \\
Diameter(cm) & $6.80^{\mathrm{a}}$ & $6.80^{\mathrm{a}}$ & 6.80 \\
Pulp thickness (mm) & $4.82^{\mathrm{a}}$ & $4.75^{\mathrm{a}}$ & 4.78 \\
Juice (\%) & $45.09^{\mathrm{a}}$ & $45.52^{\mathrm{a}}$ & 45.30 \\
Acidity (g citric acid/100g juice) & $1.164^{\mathrm{b}}$ & $1.411^{\mathrm{a}}$ & 1.287 \\
Total soluble solids ( ${ }^{\circ}$ Brix) & $11.43^{\mathrm{a}}$ & $11.18^{\mathrm{a}}$ & 11.30 \\
Number of seeds per fruit & $8.1^{\mathrm{a}}$ & $8.2^{\mathrm{a}}$ & 8.15 \\
Number of seeds per bud & $1.0^{\mathrm{a}}$ & $0.8^{\mathrm{b}}$ & 0.9 \\
\hline
\end{tabular}

Averages followed by different letters on the same line were significantly $(\mathrm{P}<0.05)$.

In 1993, sugar syrup applied to sweet orange flowers at $0800 \mathrm{hrs}$ attracted more honeybees than the untreated control flowers, which showed visitation peak at 1030 hours.

The Bee-Here ${ }^{\mathrm{R}}$ attractant diluted in sugar syrup attracted more honeybees when applied at 1200 than at 1400 hrs. However, sugar syrup pulverization led honeybees to pulverized leaves, petals, and buds in apple orchards and bean crops (5).

The Bee-Here ${ }^{\mathrm{R}}$ attractant diluted in water attracted a higher number of honeybees when applied at 0800 hrs. The 1000, 1200, and 1400 hour treatments were not different when compared to untreated control. 
In 1994, a lemon grass extract attracted more honeybees when applied at 0800 and at 1200 hrs.

Observations in 1993 and 1994 showed that lemon grass extract diluted in water applied at 0800 hrs attracted the most honeybees. The treatment that attracted the least honeybees was Bee-Here ${ }^{\mathrm{R}}$ diluted in sugar syrup applied at $1400 \mathrm{hrs.}$

In 1995, eugenol, geraniol, citral, Bee-Here ${ }^{\mathrm{R}}$, and lemon grass extract were tested. The most effective treatments were Bee-Here ${ }^{\mathrm{R}}$ followed by eugenol, citral, and geraniol; the least effective treatments were lemon grass extract and control (untreated).

Data show that the same attractants had different effect on honeybees in different years. Different climatic conditions in the observed years may have influenced attractant volatilization. Attractants may be used in crops in the morning when observing the competitive sources in region. We noticed that the product was effective for only 4 hours.

\section{CONCLUSIONS}

The most important period for pollination was the morning in the studied crops. The beginning of fructification in sweet orange flowers depends on the number of honeybee visits (at least 10 visits).

Perforation of flower buds by Trigona sp stingless bees did not decrease flower fructification.

Honeybee pollination influenced quantity and quality of fruit production. The flowers suitably visited by bees produced heavier, less acid fruit, with fewer seeds per bud.

Bee-Here $^{\mathrm{R}}$, eugenol, citral, geraniol, and lemons grass extract can be used diluted in water as honeybee attractants to sweet orange crops.

\section{ACKNOWLEDGMENTS}

We would like to thank FAPESP, CNPq, and CAPES for financial support. 
D. T. Malerbo-Souza et al. HONEY BEE ATTRACTANTS AND POLLINATION IN SWEET ORANGE, Citrus sinensis (L.) OSBECK, VAR. PERA-RIO. J. Venom. Anim. Toxins incl. Trop. Dis., 2004, 10, 2, p.151.

\section{REFERENCES}

1 AMBROSE JT., SCHULTHEIS JR., BAMBARA SB., MANGUM W. An evaluation of selected commercial bee attractants in the pollination of cucumbers and watermelons. Am. Bee J., 1995, 4, 267-71.

2 CAMERON JW., COLE JR DA., NAUER EM. Fruit size in relation to seed number in Valencia orange and some other citrus varieties. Proc. Am. Soc. Hort. Sci, 1960, 76, 17080.

3 CURRIE RW., WINSTON ML., SLESSOR KN. Effect of synthetic queen mandibular pheromone sprays on honey bee (Hymenoptera: Apidae) pollination of berry crops. $J$. Econ. Entomol., 1992, 85, 1300-06.

4 FREE JB. Studies on the pollination of fruit trees by honey bees. J. R. Hortic. Soc., 1962, 87, 302-9.

5 FREE JB. Attempts to increase pollination by spraying crops with sugar syrup. J. Apic. Res., 1965, 4, 61-4.

6 FREE JB. Dandelion as a competitor to fruit trees for bee visits. J. Appl. Ecol., 1968, 5, 16978.

7 FREE JB. Insect pollination of crops. New York: Academic Press, 1993. 544p.

8 HASSANEIN MH.., IBRAHIM MM. Studies on the importance of insects especially the honey bee in pollination of citrus in Egypt. Agric. Res. Rev., 1959, 37, 390-409.

9 JAY SC. Spatial management of honey bees on crops. Annu. Rev. Entomol., 1986, 31, 49-65.

10 KREZDORN AH. Pollination requirements of Citrus. Citrus Indus., 1972, 53, 5-7.

11 MALERBO DTS. Polinização entomófila em 3 variedades de laranja (Citrus sinensis L. Osbeck). Ribeirão Preto: Universidade de São Paulo, Faculdade de Filosofia, Ciências e Letras, 1991. 66p. [Dissertação-Mestrado].

12 MANZOORUL- HAQ., RAFIE-UL-DIN M., GHAFFAR A. Effect of insect pollination on fruit bearing in kinnow mandarin (Citrus reticulata) and physical and chemical properties of fruit. J. Apic. Res., 1978, 17, 47-9. 
D. T. Malerbo-Souza et al. HONEY BEE ATTRACTANTS AND POLLINATION IN SWEET ORANGE, Citrus sinensis (L.) OSBECK, VAR. PERA-RIO. J. Venom. Anim. Toxins incl. Trop. Dis., 2004, 10, 2, p.152.

13 MAYER DF., JOHANSEN CA. Field evaluation of chemical pollinator attractants on tree fruits. Am. Bee J., 1982, 122, 287-9.

14 MAYER DF., BRITT RL., LUNDEN JD. Evaluation of BeeScent ${ }^{\mathrm{R}}$ as a honey bee attractant. Am. Bee J., 1989, 129, 41-2.

15 McGREGOR SE. Insect pollination of cultived crop plants. Washington: Agric. Res. Serv. United States Dept. of Agric., 1976. 411p.

16 McGOURTY MA. A field evaluation of "Bee-Here ${ }^{T M "}$ a pheromone-based forage attractant for honey bees, Apis mellifera L., applied to red clover, Trifolium pratense L. Corvallis: Oregon State University, 1992. [Master of Agriculture Thesis]

17 NAUMANN K., WINSTON ML., SLESSOR KN., SMIRLE M.J. Synthetic honey bee (Hymenoptera: Apidae) queen mandibular gland pheromone applications affect pear and sweet cherry pollination. J. Econ. Entomol., 1994, 12, 1595-9.

18 OHE W. VAN DER, PRAAGH JP. VAN. Versuche zur duftlenkung in Obstanlagen. Nordwestdeustsche Imkerzeitung, 1983, 35, 100.

19 PASINI FM. Influência da polinização entomófila sobre a produção e as características dos frutos da laranjeira cultivar Piralima (Citrus sinensis Osbeck). Piracicaba: Universidade de São Paulo, Escola Superior de Agricultura "Luiz de Queiroz", 1989. 68p. [DissertaçãoMestrado].

20 ROBERTS RB. Method for assaying nectar sugar produces by plants and harvested by insects. J. N. Y. Ent. Soc., 1977, 85, 197.

21 ROBINSON FA., KREZDORN AH. Pollination of the Orlando tangelo. Am. Bee J., 1962, 102, 132-3.

22 ROBINSON WS., NOWOGRODZKI R., MORSE RA. The value of honey bees as pollinators of U.S. crops (Part I of a two-part series). Am. Bee J., 1989, 129, 411-23.

23 TREVISAN M. Importância das abelhas Apis mellifera na polinização de Citrus sinensis. In: SEMANA DE CITRICULTURA, 5, Cordeirópolis, 1983. Anais...Cordeirópolis: EEL:IAC, 1983: 269-79. 
24 VAN PRAAGH JP., OHE W. van der. The role of scents in pollination by the honeybee. Acta Hortic., 1983, 139, 65-7.

25 WAFA AK., IBRAHIM SH. (Effect of the honeybees as a pollinating agent on the yield of orange). Elfelaha, 1960, 18. In: Apic. Abstr., AA-448/63.

26 WALLER CD. Attracting honey bees to alfafa with citral, geraniol and anise. J. Apic. Res., 1970, 9, 9-12.

27 WINSTON ML., SLESSOR KN. Applications of honey bee queen mandibular pheromone for beekeeping ("Bee Boost") and crop pollination ("Fruit Boost"). Bee World, 1993, 74, 111-28.

28 WOYKE HW. Some aspects of the role of the honeybee in onion seed production in Poland. Acta Horticulture, 1981, 111, 91-98.

29 ZAVRASHVILI RM. (Bees and the citrus crop). Pchelovodstvo, 1964, 84, 19. In: Apic. Abstr., AA-347/66. 